\title{
Reflection of Constructivist Theories in Current Educational Practice
}

\author{
Alena Juvova, Stefan Chudy, Pavel Neumeister, Jitka Plischke, Jana Kvintova* \\ Faculty of Education, Palacky University in Olomouc, Czech Republic \\ *Corresponding Author: janakvintova@seznam.cz
}

Copyright $@ 2015$ Horizon Research Publishing All rights reserved.

\begin{abstract}
In this overview study, we would like to present the basic constructivist approaches that have affected or influenced the current concept of education. The teacher-student interaction is reflected by personality, psychological traits, attitudes and cultural capital of the participants of the educational process as well as the teacher's effort to mediate the didactic content to the students. Concerning the changing roles of the teacher and the student, which is followed by a concept based on pedagogical constructivism, it is also important to accept the need for adequate training of undergraduate teachers and further education of teachers in practice. The present discourse analysis will focus on the implementation of constructivist theory in educational theory and didactics.
\end{abstract}

Keywords Constructivist theories, Didactics, Education

\section{Introduction}

Despite the fact that today's rapidly changing society has, in terms of its requirements for a human, a clear vision of its direction and pragmatically considers the economic and political attributes of a human personality, school preparation of an individual who should meet these declared needs is stagnating. A conservative view of preparing students for life, which is applied through scientific knowledge in the field of cognitive science and education, can result in serious social and especially educational problems.

Although the dominant element of education is still the family, it is obvious that the school and the teacher are the mediators in the process of implementing socially desirable values. Therefore, we consider it necessary to contribute to the discussion about the value of education and educational process in the reflection of the modern concept of education, especially in terms of pedagogical constructivism [1].

An approach taken in order to clarify the meaning of pedagogical constructivism combines the knowledge of Piaget $[2,3]$ with an acceptance of environmental influences that impact the learner. Therefore, learner activity and development get into the centre of attention. This fact changes the paradigm of the relationship between the teacher and the student, in other words the educator and the educated. While the student was traditionally viewed as an object of education that is taught, while the central figure in the teaching process was the teacher, currently the student is regarded an educational subject who, to some extent, manages his/her education actively and independently (so-called self-controlled/self-regulated learning). According to this understanding, the teacher gets into the role of a guide, tutor, or mentor. This must also be necessarily reflected in the concept of didactics, which is one of the basic disciplines in the professional training of teachers.

It is possible to create a transdisciplinary didactic model of subjective didactics, or, in other words, the implicit theories of teaching, which is influenced by the knowledge of cognitive sciences (e.g., neuropsychology, evolutionary psychology, cognitive psychology, positive psychology, psychoneuroimmunology), taking into consideration the findings of pedagogical constructivism, theories of education, education of reformation, neuropedagogy, neurodidactics or system theories [4, 5]. This model has been recently developed into the so-called inclusive didactics [6].

The model of subjective didactics formulated by E. Kosel [5] is built on the knowledge of constructivist-system epistemology and knowledge of neurophysiology and psychoneuroimmunology. It follows the principle of self-organized learning with the prospect of lifelong learning and uses possibilities of e-learning and ICT [7]. The approach to subjective didactics is based on systematic understanding of the goals, contents, methods and resources; it is related to the changing role of the teacher and the associated requirement to change the quality of social interactions between the teacher and the student.

We attempt to find an interaction between the concepts of evolutionary, cognitive and educational psychology and pedagogy by means of a discourse analysis. Discursive universality is interpreted as a set of phenomena and their relations within subjective didactics. 


\section{Pedagogical Constructivism and Didactics}

Constructivism in education (pedagogical constructivism) is primarily based on Piaget's concept of cognitive development as a specific form of biological adaptation [2,3] and also on the work by Vygotskij [8], Bruner [9] and others. Piaget [3] distinguishes four basic stages in the development of a child's thinking, which follow after the period of the development of sensory motor intelligence, during which a child creates own views of the world based on motor activity through which the child defines the environment.

Bruner [9] worked on the theory of instrumental conceptualism in 1960s. According to this concept focused on the individuality of the learner, learning is a process during which the student actively deduces and verifies principles and rules. It is a kind of a subjective way in which the learner handles information. The basic principles of a change in the concept of the learning process were laid by Maturana, Varela [10], when conceived notion of autopoiesis, further developed by Luhmann [11] in his theory of social systems.

In general, pedagogical constructivism is perceived to be “... stimulating learners to interactivity, social communication and to the development of their own knowledge, structures of knowledge and to critical assessment of information, the transition from 'teaching you' (transmitted teaching) to 'teaching myself', to self-initiation, self-organization and self-evaluation" [12]. The so-called holistic - Gestalt psychology has also significantly contributed to the learning theory since the 1920s. Its representatives have criticized associanism and the learning theory based on conditioning. The fundamental idea of the learning theory based on insight learning is the idea that the wholeness is more than the sum of its parts; however, their organization of structure - "shape" is of equal importance.

Further directions of the learning theory have been developed since the sixties in connection with the development of neurobiological research, whose representatives were e.g. Lorenz, founder of ethology, Pribram and others. The neurophysiological nature of learning and applications of brain research were also dealt with by Vester [13], who emphasized the need for a reflection of this knowledge in the educational process. He precisely describes the process of learning based on a network of brain activities.

In the Czech Republic and Slovakia, the theory of learning was dealt with by Slovák [14], who developed principles of his own reflective learning theory based on a traditional reflective theory by I. P. Pavlov. Constructivist theories developed abroad were then further developed by Pupala [15], Petlák [16], Škoda, Doulík [17], Janík [18] and others.

According to Siebert [19], three complementary pedagogical ideas are important in the constructivist learning theories of pedagogy: a constructivist notion of VIABILITY, which is understood as a necessary, useful, functional way in the learning process, environmental concept of PERMANENCE, SUSTAINABILITY, STABILITY, and an enlightenment notion of SENSE.

The reality of the learning process is "constructed" on the basis of certain individual preconceptions, and new knowledge is integrated into the existing structures. "These representations stand for the current decoding structures that give meaning to the gathered information as well as for a receiving structure, which may allow incorporation of new facts. Their role is that of a mediator between the knowledge structures and individual thinking - the student develops own knowledge by implementing the interaction between these preconceptions and information that can be obtained from them" [20]. In this sense, the main phenomenon is a language as a meaningful and symbolic system, by which an individual creates an own version of the surrounding environment - the world. "Constructivism defines conversational reality as a social environment that people create by means of repeated comparison and reconciliation of their individual realities" [21]. Based on the constructivist theory of learning, the following three basic concepts can be distinguished [19]:

1. Learning is the reflection of teaching - constructivism does not admit the fact that the self-realization can be determined, instructed, and informed from the surrounding environment.

2. Learning is an adoption of reality - the learner's own activity is emphasized, however it attributes cognitive openness to reality and is based on a single representative model.

3. Learning is an autonomously controlled cognitive system, which interacts with its own conditions, this differentiates and modifies the independence of its own structure. This is a radically constructivist thesis.

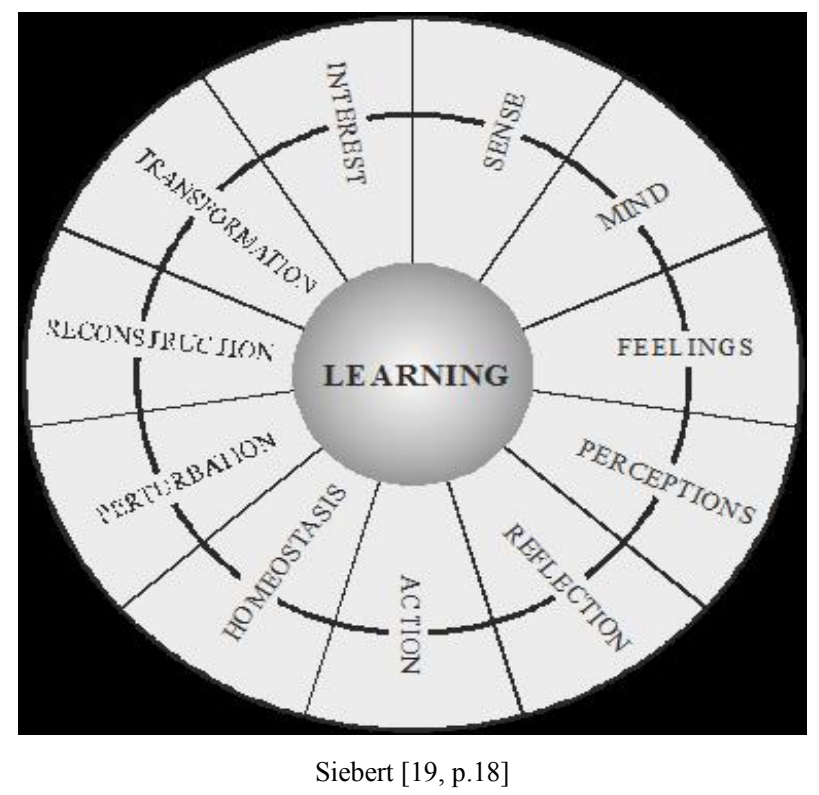

Figure 1. Constructivistic learning

In accordance with the constructivist theory and the findings of modern neuroscience, the traditional concept of 
didactics has also changed. So far, didactics has studied the transmissive approach to teaching, i.e. through a process of knowledge transfer from the teacher to the student, in which the primary emphasis is placed on facts and their memorization. In the constructivist approach the understanding of the problem is required, as well as searching for a broader context and a systemic approach, without the teacher's losing hope in the student's knowledge of the necessary facts [6].

In relation to general didactics it is possible, on a constructivist basis, to encounter terms such as neurodidactics, psychodidactics, constructivist didactics, subjective didactics, and inclusive didactics. A discipline defined in this way requires understanding of the educational process in terms of the learner's individual physiology, without questioning the traditional didactic structure of the relationship between the teacher and the student, who are in their mutual interactions in a particular environment and they together attempt to achieve the educational objectives with the help of didactic methods, forms and tools (see Figure 2).

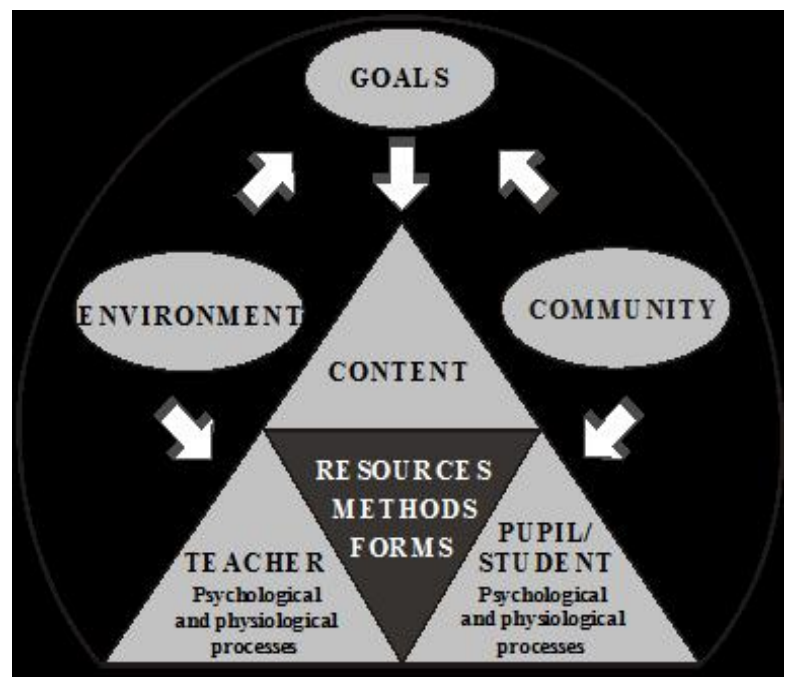

Figure 2. The didactic triangle in terms of neurodidactics

In the current concept of school education, an effort to involve the student in an active way in the learning process is promoted; however, according to the behaviourist concept of learning, direct management of teaching requires an instructional approach. Self-managed learning and active involvement of the student should be applied in order to develop the ability to generalize, understand the context and associate (so-called the functional literacy).

The principles of pedagogical constructivism can be characterized as follows [22, 23, 24, 25]:

- emphasis on activity and increasing the student's motivation for learning

- systematic approach to problem solving, finding connections, associations, interdisciplinary transfer

- maintaining the principle of continuity and consistency

- application of teaching methods according to student typology (different types of intelligence, personality, learning styles)

- individual approach to the student based on his/her mental development

- mutual communication between the teacher and the student, the teacher can learn from the student

- preparation for teamwork - synergy

- action learning, learning from research

- communication and interaction with the student's family

- cooperation with school representatives (from the school internal and external environment), education of a community nature

- work with an error and failure.

In connection with a constructivist oriented approach to learning, a requirement for the use of appropriate, modern teaching resources arises. This primarily concerns adequate teaching resources, nowadays especially multimedia and ICT. Textbooks should be therefore compiled in accordance with the new constructivist knowledge. "There is no doubt that the constructivist knowledge brought important impulses to teaching natural sciences. The main learning difficulties are nowadays revealed and clarified in the context of these findings. Therefore, they also provide a framework that will lead to the development of new effective study books and teaching methods" [26].

\subsection{Pedagogical Constructivism in Teacher Training, Preconceptions and Teachers' Competences}

The educational process is understood as a set of teachers' complementary activities based on their professional competence. These competences are used to derive theoretical knowledge and practical skills that are reflected as an individualized set in the teacher's conduct strategies. Beside these obvious educational activities, the interaction between the teacher and the student is affected by the teacher's personality traits, psychological traits, attitudes and cultural capital, all of which are reflected in the concept of the teacher's individual educational influence.

While the teacher's educational activities in the classroom are quite well observable, it is more difficult to recognize his/her upbringing activities. Obvious signs of the teacher's upbringing influence are based on the "teacher's individual concept of upbringing activities." The teacher selects those procedures, principles and rules from this set, which he/she considers appropriate and effective for his/her upbringing activities.

The issue of pedagogical constructivism in teacher training is discussed by Spilková [27]. According to her, the personality and constructivist concept of teacher training should be the theoretical basis of the contemporary transformation of teacher training in the whole Europe. These concepts by Spilková [27] “... emphasize personal growth, the individual process of gradual becoming a teacher' in the sense of active development and a creative way of becoming a teacher, based on their own activities, experience, self-understanding, their own searching and 
discovering of students in cooperation with teachers and fellow students."

For effective teaching, the teacher requires an extensive knowledge base and many specific skills and abilities. In the current constructivist theories, the teacher's individual perception of educational reality through the production of subjective preconceptions is considered to be a basis for his/her perception of education. These preconceptions then create a unique and personalized ontology of education. A verification of the student's understanding of the curriculum in a close liaison with the method of conceptual mapping is also very frequent, not only as a diagnostic method, but also as an exposure or intervention method [28, 30].

Four dimensions of preconception as stated by Skoda, Doulík [29]:

- Knowledge dimension is characterized by its content and scope, and is therefore detectable by didactic tests.

- The second dimension is the affective one, which is characterized by an individual's attitude to a given concept. Diagnostic tools can include a traditional questionnaire but also non-traditional methods such as the semantic differential and associative or projection methods.

- The third dimension is a pre-conceptual construct in an individual's cognitive map. This construct captures not only the relations between the concepts and their hierarchy, but also their mutual relations. This dimension can be diagnosed by cognitive mapping.

- The last of the defined dimensions is plasticity of preconception. It is understood as an ability of preconception to flexibly respond to the additionally received pieces of information that are confronted with the initial preconception, and adapt to them. The plasticity aspect can be assumed only indirectly, having the knowledge of the previous dimensions.

In order for the teacher to work well educationally, he/she requires an extensive knowledge base; many specific skills and abilities that allow him/her to fulfil this role (see Teaching - National Qualification Framework). It is therefore necessary to primarily focus on the knowledge base, which we consider as essential in this respect.

Conceptual and curricular changes in primary and secondary schools, point to an insufficiently formed foundation of educational strategies and related phenomena (coping with marginal or critical educational situations, discipline, freedom, authority, teacher, etc.) Only a teacher who is closely acquainted with the nature of the learning process on a neurochemical level can approach the student holistically, i.e. in accordance with the theory of Gestalt psychology, as to a self-realized individual, to respect the student's age and psychological traits and know how to treat the student - no criticism, no assessment, acceptance of the students, cultivation of the student's potential. This is a diagnosis, not a classification.

\subsection{Methods of Application in Professional Teacher Training}

The Change of the teacher-student paradigm and laying the foundation for the acceptance of the concept of self-managed (self-regulated) learning in school practice is necessary in professional training.

Teacher training faces tasks and perspectives that are reflected in the requirements for the teacher personality and characterized by the following basic phenomena:

- development of soft skills

- perfect knowledge of the content of the curriculum

- confidence, self-efficacy

- ability of a critical view

- generosity and flexibility

- value orientation.

In the teacher-student interaction two distinctive individual systems "meet", in the first place it is necessary to "tune" to the same wavelength - social and pedagogical consensus. The following is then required:

- motivation

- respect of biological, psychological and social particularities of the student

- mastery of educational psychology

- working with failures.

The requirement of lifelong learning:

- Individual preparation and training of pedagogical situations in a "protected environment".

- Crossing the comfort zone.

- Transactional analysis.

- Identifying the needs of students, teachers, school management, parents, society.

The teachers must have sufficient professional competence and an elaborated comprehensive plan of personality development, which focuses on the development of morality, sociability, character and respect for the cultural and environmental values. The student will create, on the basis of values and value-based relationships, his/her own system of self-regulation concerning all components of life.

Schools should see their educational function in acquiring knowledge and value orientation aimed at interiorizing values and principles of health and healthy lifestyle. The presented tasks must be reflected in the content of education, which requires effective intervention in order to create a life philosophy that health and healthy lifestyle reinforces the value of human being and allows greater cooperation with other environments.

The content of education should be capable of organizing identified values into a value system, which is typical for a particular society, culture or an individual, and guide the student toward these values. Values give a sense to the human life and, in the content of education, create the basis for value orientation in students; therefore, we aimed to clarify their importance and role on a theoretical level.

A teacher knowledgeable about the nature of the teaching process respects student and treat them holistically (in 
accordance with the bio-psychosocial concept of personality), and reflects their own personalities and performance. Practical teaching can only result from a thoroughly mastered theory of education. It can no longer be accepted that it is possible to obtain adequate pedagogical competence without prior thorough theoretical pedagogical psychological as well as personal and professional training. Once in practice, it is too late to achieve the above mentioned. Even a novice teacher is a bearer of progression rather than stagnation and such teacher's action research should contribute to prognosticating in the field of education [31].

\section{Acknowledgements}

This Article is dedicated to projects:

IGA_PdF_2015_022 The phenomena of relationships between education and thinking in constructivism education.

Internal grant of PDF UP: From subjective implicit theories of education to teaching knowledge. The process of constitution of a cognitive framework sciences education in the national and international context.

\section{REFERENCES}

[1] Chudy S, Neumeister P. Specification of assumptions to outline the category " value" in the curriculum. Acta humanita, 2011, 8 (1): 6-31.

[2] Piaget J. The psychology of intelligence. Prague: SPN, 1970.

[3] Piaget J. The psychology of intelligence. Prague: Portál, 1999.

[4] Wilhelm Marianne. Entwicklungsdidaktik als Antwort auf den Anspruch der individualisierung in der inklusiven Schule. Zeitschrift fuer Inklusion, 2012. Retrieved from: http://www.inklusion-online.net/index.php/inklusion-online/ article/view/64/64.

[5] Koesel E. ABC der subjektiven Didaktik. Bahlingen: SD-Verlag, 2001.

[6] Reich Kersten. Inklusive Didaktik. Bausteine fuer eine inklusive Schule. Weinheim und Basel: Beltz, 2014.

[7] Kohlberg L. Essays on Moral Development, Vol. I: The Philosophy of Moral Development. San Francisco, CA: Harper \& Row, 1981.

[8] Vygotskij L. S. The psychology of thinking and speech, Prague: Portal, 2004.

[9] Bruner J. S. The process of education. Cambridge, Mass: Harvard University Press, 2003.

[10] Maturana H, Varela F. Autopoiesis and Cognition. The Realization of the Living. Dordrecht: Reidel, 1980, p. 13.

[11] Luhmann Niklas. Social systems: delineation of the general theory. Brno: CDK, 2006.

[12] Kohoutek R. Pedagogical constructivism. Retrieved from: ht tp://slovnik-cizich-slov.abz.cz/web.php/slovo/pedagogicky-k onstruktivismus.

[13] Vester F. Denken, Lernen, Vergessen.Was geht im unseren Kopf vor, wie lernt dass Gehirn, und wann laesst es uns im Stich? Aktualisierte Neuausgabe. München: DTV, 2002.

[14] Sovak Milan. Biological basic of learning. Prague: SPN, 1985.

[15] Kascak O, Pupala B \& Petrova Z. Humanism and autonomy in the neoliberal reform of teacher training. In Education, Knowledge and Economy, 2011, 5 (1-2): 71-88.

[16] Petlak Erich. Pedagogical and didactic teacher's work, Bratislava: IRIS, 2007.

[17] Skoda J, Doulík P. The development of paradigms in natural science education. Pedagogical orientation, 2009, 19(3): 2444.

[18] Janik Tomas. et al. Pedagogical content of knowledge or didactic knowledge of content? Brno: Paido, 2007.

[19] Siebert, A. How resilient are you. New York: Guilford Press, 1999 , p. 49.

[20] Bertrand Yann. Contemporary Theories of Education. Portal, Prague, 1998, p. 69.

[21] Lazarova B. The possibilities of reflexive work in teacher education. In Educating teachers. Contributions to innovative practice. Brno: Paido, 2001, pp. 54-70.

[22] Brdicka B. Role of Internet in education, 2003. Retrieved from: http://it.pedf.cuni.cz/ bobr/role/ccont.htm.

[23] Hejny M, Novotna J, Stehlikova N. Twenty- five chapters of mathematics education, Prague: PedF UK, 2004.

[24] Molnar J, Schubertova S \& Vanek V. Constructivism in teaching mathematics. UP Olomouc, 2007, pp. 80.

[25] Dostal, P. Soft Computing Methods in Business Optimization. Global Journal of Technology \& Optimization, 2013, 4 (1), pp. 20-21.

[26] Duit Reinders. Zuer Rolle der konstruktivischen Sichtweise in der naturwissenschafts-didaktischen Lehr- und Lernforschung. Zeitschrift fuer Paedagogik,1995, 41(6): 905-923.

[27] Spilkova Vladimira. Prospects of teacher education- foreign and domestic trends, the situation at the faculty, 2003. Retrieved from: http://www.alfa.pedf.cuni.cz/svi/informatori um/ cislo32/vyd_ped3.html.

[28] Pupala B, Osuska L. The development of children's concepts of the digestive system and digestion. Children psychology and abnormal psychology. 1987, 1: 35.

[29] Skoda J, Doulik P et al. Current issues of selected didactics. Usti nad Labem: UJEP, 2009, pp. 235.

[30] Andrysova, P., Martincova, J., Vcelarova, H. Pedagogical Condition at Undegraduate Teacher Preparation. The New Educational Review, 2014, 38, 4., 152-165. ISSN 978-83-8019-051-1.

[31] Novotna, J. Critical Thinking in Education. STS Science Centre: London, 2014. ISBN 978-1-908235-06-0. 